\title{
Pretreatment of Food Industry Wastewater by Coagulation: Process Modeling and Optimization
}

\author{
Senem Yazıcı Güvenç, Emine Can Güven* \\ Department of Environmental Engineering, Faculty of Civil Engineering, Yıldız Technical University, Istanbul, \\ Turkey \\ *ecguven@yildiz.edu.tr
}

Received: 24 June 2019

Accepted: 13 September 2019

DOI: $10.18466 /$ cbayarfbe.581611

\begin{abstract}
In this study, coagulation processes using $\mathrm{FeCl}_{3} 6 \mathrm{H}_{2} \mathrm{O}$ and $\mathrm{Al}_{2}\left(\mathrm{SO}_{4}\right)_{3} 18 \mathrm{H}_{2} \mathrm{O}$ as coagulants were employed and designed for chemical oxygen demand (COD) and total suspended solids (TSS) removal from food industry wastewater via response surface methodology (RSM). RSM was used for the optimization of coagulation processes and evaluation of the effects and interactions between process variables $(\mathrm{pH}$, coagulant dosage and reaction time). ANOVA was used to analyze the experimental data obtained in the study and secondary regression models were developed by using Statgraphics Centurion XVI.I software. The optimum conditions were $\mathrm{pH} \mathrm{9}$, dosage $1500 \mathrm{mg} / \mathrm{L}$ and time $25 \mathrm{~min}$ for maximum COD removal efficiency for $\mathrm{FeCl}_{3} 6 \mathrm{H}_{2} \mathrm{O}$ and $\mathrm{pH} 9$, dosage $1493 \mathrm{mg} / \mathrm{L}$ and time $25 \mathrm{~min}$ for $\mathrm{Al}_{2}\left(\mathrm{SO}_{4}\right)_{3} 18 \mathrm{H}_{2} \mathrm{O}$. Under optimum conditions, COD and TSS removal efficiencies were $46.4 \%$ and $96.7 \%$ for $\mathrm{FeCl}_{3} 6 \mathrm{H}_{2} \mathrm{O}$ and $31.2 \%$ and $96.2 \%$ for $\mathrm{Al}_{2}\left(\mathrm{SO}_{4}\right)_{3} 18 \mathrm{H}_{2} \mathrm{O}$, respectively. ANOVA results showed that the responses of model have high coefficient values $\left(\mathrm{R}^{2}>0.80\right)$, and hence the second order regression model can be explained with these experimental data. The proposed model fits very well with the experimental data with $\mathrm{R}^{2}$ of 0.9677 for COD and 0.9543 for TSS removal for $\mathrm{FeCl}_{3} 6 \mathrm{H}_{2} \mathrm{O}$ and 0.9456 for COD and 0.9260 for TSS removal for $\mathrm{Al}_{2}\left(\mathrm{SO}_{4}\right)_{3} 18 \mathrm{H}_{2} \mathrm{O}$, respectively. Model results showed that the $\mathrm{RSM}$ for coagulation processes using both coagulants is a powerful tool for optimizing the experimental conditions. Moreover, it can be concluded that both coagulation processes may be an effective alternative pre-treatment process for food industry wastewater.
\end{abstract}

Keywords: $\mathrm{Al}_{2}\left(\mathrm{SO}_{4}\right)_{3} 18 \mathrm{H}_{2} \mathrm{O}$, Coagulation, $\mathrm{FeCl}_{3} 6 \mathrm{H}_{2} \mathrm{O}$, Optimization, RSM.

\section{Introduction}

Wastewater treatment is important for protection of natural resources. Besides conventional physical and biological treatment applications coagulation/flocculation is an essential process in domestic and/or industrial wastewater treatment. Coagulation/flocculation process stands out as a pretreatment method that can be applied before biological treatment in order to increase the efficiency [1]. This process, in which coagulants such as iron (II) sulfate, iron (III) chloride, iron chlorosulfate $\left(\mathrm{FeClSO}_{4}\right)$, and aluminum sulfate (alum) are widely used [2], is applied in water/wastewater treatment to convert colloidal materials into easily settable aggregates [3]. Coagulation/flocculation process is very effective in the removal of organic matter and suspended solids [4]. Although alternatives have been tried to be developed since the process causes residual metal ions in treated water, low efficiency of synthetic polymers in addition to low cost, ease of operation and energy efficiency of coagulation/flocculation process [1], an easily feasible treatment alternative method to metal ions could not have been developed [5].

Coagulation process efficiency depends on many variables such as coagulant type, coagulant dosage, $\mathrm{pH}$, property of wastewater, and addition of flocculants [6]. Many studies have been conducted to optimize process parameters in treatment of landfill leachate, industrial wastewater, domestic wastewater, and wastewater from animal farms [1,3]. $\mathrm{FeCl}_{3} \cdot 6 \mathrm{H}_{2} \mathrm{O}$ and $\mathrm{Al}_{2}\left(\mathrm{SO}_{4}\right)_{3} 18 \mathrm{H}_{2} \mathrm{O}$ are commonly used coagulants in the treatment of industrial wastewaters and it has been applied to wastewaters from different industries such as potato chips production, soap/detergent production, and cork production [3].

Food industry wastewaters mainly contain leavenings, carbohydrate, organic and inorganic salts, oil and grease, cleaning products and proteins which are difficult to treat by conventional physicochemical pretreatment applications [7]. Conventional biological processes applied for the treatment of these wastewaters are insufficient to meet discharge standards in many 
countries and new treatment methods are needed [8]. Thus, researchers have recommended addition of chemical coagulants for treatment of these wastewaters $[9,10]$. Moreover, coagulation process was used as a pretreatment application in the treatment of various food industry wastewaters. $\mathrm{Al}_{2}\left(\mathrm{SO}_{4}\right)_{3}$ was used as coagulant to treat wastewaters from instant coffee and coffee products [11] and table olive processing [12] while $\mathrm{FeCl}_{3}$ was applied in the pretreatment of vegetable processing [13] and table olive processing [12] wastewaters.

In order to achieve high treatment performances, optimization of process parameters is needed. Traditionally, optimization of process is conducted by determining the effect of one factor while the others are held constant [14]. However, this application is disadvantageous both in terms of time and evaluating the effect of different factors together [15,16]. Therefore, statistical methods are practical for minimizing the time required for experiments, reducing cost and evaluating the effects of many factors together. For this purpose, response surface methodology (RSM) is commonly used for modeling of various variables and optimization of operation parameters $[14,16]$. The most widely used method in RSM is central composite design (CCD) which is an effective method that demonstrates the effect of binary interaction and curvilinear variables [16].

In this study, application of coagulation with $\mathrm{FeCl}_{3} 6 \mathrm{H}_{2} \mathrm{O}$ and $\mathrm{Al}_{2}\left(\mathrm{SO}_{4}\right)_{3} 18 \mathrm{H}_{2} \mathrm{O}$ as coagulants for removal of total suspended solids (TSS) and chemical oxygen demand (COD) from food industry wastewater was investigated. The operational parameters such as coagulant type and dosage, $\mathrm{pH}$, and operation time were optimized using CCD as a statistical experimental design.

\section{Materials and Methods}

\subsection{Food Industry Wastewater}

The characteristics of real wastewater used in this study are given in Table 1. Food industry wastewater was obtained and analyzed according to the Standard Methods [17]. COD was measured by closed reflux titrimetric method and TSS was determined by $2540 \mathrm{D}$ method of APHA [17]. The $\mathrm{pH}$ and electrical conductivity were measured using WTW Multi 9620 IDS device.

\subsection{Experimental and Analytical Procedure}

$\mathrm{FeCl}_{3} 6 \mathrm{H}_{2} \mathrm{O}$ and $\mathrm{Al}_{2}\left(\mathrm{SO}_{4}\right)_{3} 18 \mathrm{H}_{2} \mathrm{O}$ coagulant solutions were prepared as $10 \mathrm{~g} / \mathrm{L}$. The $\mathrm{pH}$ of wastewater $(400$ $\mathrm{mL}$ ) was adjusted to the desired level using few drops of $1 \mathrm{~N} \mathrm{H}_{2} \mathrm{SO}_{4}$ and $1 \mathrm{~N} \mathrm{NaOH}$ solutions before each sets. And then, initial electrical conductivity of wastewater was measured and recorded. The coagulant dosage (500, 1000 and $1500 \mathrm{mg} / \mathrm{L}$ ) determined by CCD was added to the wastewater sample placed in the jar-test apparatus. After mixing rapidly during $1 \mathrm{~min}$ at $200 \mathrm{rpm}$ and slowly for desired time at $30 \mathrm{rpm}$, the liquid was settled for one hour, then; the supernatant was collected to measure COD and TSS.

Table 1. Characteristics of real wastewater used in this study.

\begin{tabular}{lc}
\hline Parameter & Value \\
\hline $\mathrm{pH}$ & 6.09 \\
$\mathrm{COD}, \mathrm{mg} / \mathrm{L}$ & 17,600 \\
Conductivity, $\mathrm{mS} / \mathrm{cm}$ & 4.08 \\
$\mathrm{TSS}, \mathrm{mg} / \mathrm{L}$ & 940 \\
\hline
\end{tabular}

\subsection{Design of the Experiments}

Statistical methods of experimental design can consider the interactions of the factors, while the required number of experimental set is limited. Therefore, many researchers have recently interested in the methods for optimization of wastewater treatment. RSM, which is one of the experimental design statistical tools, can optimize the operational factors and also develop a mathematical descriptive model for the process [18]. In this study, CCD model for coagulation processes using $\mathrm{FeCl}_{3} 6 \mathrm{H}_{2} \mathrm{O}$ and $\mathrm{Al}_{2}\left(\mathrm{SO}_{4}\right)_{3} 18 \mathrm{H}_{2} \mathrm{O}$ coagulants was used for producing the effects of experimental parameters on COD and TSS removal from food industry wastewater.

15 experimental sets representing the interactions between independent variables and optimizing the parameters were conducted with 3 different levels of $\operatorname{CCD}(-1,0,+1)$ and with 3 independent variables. The ranges of three most important variables $\left(X_{1}: p H, X_{2}\right.$ : coagulant dosage and $\mathrm{X}_{3}$ : reaction time) are given in Table 2. According to the preliminary study results, the coded values of the independent variables were specified. Also, the ranges of the independent variables were determined and given in Table 2. The experimental design and statistical analysis of data were performed using the Statgraphics Centurion XVI.I software. The suitability of the secondary model was verified using the $\mathrm{R}^{2}$ correlation coefficient, the student t-test assessed its statistical significance, and the conditions of the model were checked using probability (p) values at a confidence interval of 95 percent. The significance level of the model and each factor can be interpreted from obtained results from variance analysis of the model. $\mathrm{R}^{2}$ expressed the fit quality of the polynomial model and Fisher's F-test verified its statistical significance. The model terms were evaluated by their p-value and F-value.

The relationship between the independent variables and responses is shown by Eq. (2.1).

$$
\begin{aligned}
Y=b_{0}+ & \sum_{j=1}^{n} b_{j} x_{j}+\sum_{j=1}^{n} b_{j j} x_{j}^{2} \\
& +\sum_{i} \sum_{<j=2}^{n} b_{i j} x_{i} x_{j}+e_{i}
\end{aligned}
$$


Table 2. The coded values of variables of the experimental design matrix.

\begin{tabular}{llllll}
\hline Coagulant type & Symbol & Factor & \multicolumn{3}{c}{ Coded variables } \\
\hline & & & -1 & 0 & 1 \\
\hline \multirow{2}{*}{$\mathrm{FeCl}_{3} 6 \mathrm{H}_{2} \mathrm{O}$} & $\mathrm{X}_{1}$ & $\mathrm{pH}$ & 5 & 7 & 9 \\
& $\mathrm{X}_{2}$ & Dosage, $\mathrm{mg} / \mathrm{L}$ & 500 & 1000 & 1500 \\
& $\mathrm{X}_{3}$ & Reaction Time, min. & 5 & 15 & 25 \\
\hline Coagulant type & Symbol & Factor & \multicolumn{2}{l}{ Coded variables } \\
\hline & & & -1 & 0 & 1 \\
\hline & $\mathrm{X}_{1}$ & $\mathrm{pH}$ & 5 & 7 & 9 \\
$\mathrm{Al}_{2}\left(\mathrm{SO}_{4}\right)_{3} 18 \mathrm{H}_{2} \mathrm{O}$ & $\mathrm{X}_{2}$ & Dosage, mg/L & 500 & 1000 & 1500 \\
& $\mathrm{X}_{3}$ & Reaction Time, min. & 5 & 15 & 25 \\
\hline
\end{tabular}

where $\mathrm{Y}$ is the assumed response (COD and TSS removal); $b_{0}$ is the constant coefficient; $b_{i}, b_{i i}$ and $b_{i j}$ are the coefficients for the linear, quadratic and interaction effects respectively; $X_{i}$ and $X_{j}$ are the independent variables; $\mathrm{n}$ is the number of independent variables, and $\mathrm{e}$ is the error of prediction.

\section{Results and Discussion}

\subsection{Statistical Analysis by CCD}

To fit the experimental findings acquired by CCD, quadratic polynomial surface reaction model was implemented. The regression equations obtained in coagulation process for COD and TSS removal are presented as shown in Eq. (3.1-3.4).

In Eq. (3.1-3.4) $X_{1}, X_{2}$, and $X_{3}$ show the effects of the linear main factor, while $\mathrm{X}_{1} * \mathrm{X}_{2}, \mathrm{X}_{1} * \mathrm{X}_{3}$ and $\mathrm{X}_{2} * \mathrm{X}_{3}$ and $\mathrm{X}_{1}^{2}, \mathrm{X}_{2}^{2}$ and $\mathrm{X}_{3}^{2}$ show the interaction between the two factors and the quadratic effects, respectively. The positive sign of coefficients indicates a synergistic effect, whereas the negative sign of coefficients indicates an antagonistic effect. According to Eq. (3.13.2) it can be seen that COD and TSS removal efficiencies increase with rising $\mathrm{pH}$ but decrease with rising dosage. Also, COD removal efficiency decreases with increase in reaction time, whereas TSS removal efficiency increases with increase in reaction time in Eq (3.1-3.2). In Eq. (3.3-3.4), COD and TSS removal efficiencies increase with increase in $\mathrm{pH}$ and reaction time but decrease with increase in dosage.

Three independent variables were analyzed as responses COD and TSS removals, in order to obtain optimum initial $\mathrm{pH}$, coagulant dosage and reaction time and to achieve highest removal of COD and TSS for the treatment of food industry wastewater using $\mathrm{FeCl}_{3} 6 \mathrm{H}_{2} \mathrm{O}$ and $\mathrm{Al}_{2}\left(\mathrm{SO}_{4}\right)_{3} 18 \mathrm{H}_{2} \mathrm{O}$ coagulants. The experimental design and actual values of responses by $\mathrm{FeCl}_{3} 6 \mathrm{H}_{2} \mathrm{O}$ and $\mathrm{Al}_{2}\left(\mathrm{SO}_{4}\right)_{3} 18 \mathrm{H}_{2} \mathrm{O}$ coagulants are given in Table 3 and Table 4, respectively. ANOVA results from obtained process using $\mathrm{FeCl}_{3} 6 \mathrm{H}_{2} \mathrm{O}$ and $\mathrm{Al}_{2}\left(\mathrm{SO}_{4}\right)_{3} 18 \mathrm{H}_{2} \mathrm{O}$ coagulants were given in Table 5 and Table 6 . The findings indicate a high level of reliability in COD

$\mathrm{FeCl}_{3} 6 \mathrm{H}_{2} \mathrm{O}$ coagulant;

COD removal, $\%$

$$
\begin{aligned}
& =22.0125+4.70625 * X_{1}-0.01805 * X_{2}-1.57875 * X_{3}-0.44375 * X_{1}{ }^{2} \\
& +0.001675 * X_{1} * X_{2}+0.06 * X_{1} * X_{3}+0.0000058 * X_{2}{ }^{2}+0.000565 * X_{2} * X_{3} \\
& +0.02275 * X_{3}{ }^{2} \\
\text { TSS removal, } \% & =37.9875+12.8875 * X_{1}-0.11125 * X_{2}+4.605 * X_{3}-0.6875 * X_{1}{ }^{2}+0.001 \\
& * X_{1} * X_{2}-0.16 * X_{1} * X_{3}+0.0000576 * X_{2}{ }^{2}-0.00028 * X_{2} * X_{3}-0.0855 \\
& * X_{3}{ }^{2}
\end{aligned}
$$

$\mathrm{Al}_{2}\left(\mathrm{SO}_{4}\right)_{3} 18 \mathrm{H}_{2} \mathrm{O}$ coagulant;

$$
\begin{aligned}
\text { COD removal, \% } & \\
& =5.6875+3.375 * X_{1}-0.0003 * X_{2}+0.075 * X_{3}-0.1875 * X_{1}{ }^{2}+0.00025 \\
& * X_{1} * X_{2}+0.0 * X_{1} * X_{3}+0.0000022 * X_{2}{ }^{2}+0.00005 * X_{2} * X_{3}-0.002 * X_{3}{ }^{2} \\
\text { TSS removal, \% } & =55.65+3.81458 * X_{1}-0.00681667 * X_{2}+0.22625 * X_{3}-0.151042 * X_{1}{ }^{2} \\
& +0.00015 * X_{1} * X_{2}+0.00375 * X_{1} * X_{3}+0.0000112833 * X_{2}{ }^{2}-0.00043 * X_{2} \\
& * X_{3}+0.0174583 * X_{3}{ }^{2}
\end{aligned}
$$


estimation of COD and TSS removal efficiencies of $\mathrm{R}^{2}$ values of 96.77 and 95.43 for $\mathrm{FeCl}_{3} 6 \mathrm{H}_{2} \mathrm{O}$ coagulant, 94.56 and 92.59 for $\mathrm{Al}_{2}\left(\mathrm{SO}_{4}\right)_{3} 18 \mathrm{H}_{2} \mathrm{O}$ coagulant, respectively. High $\mathrm{R}^{2}$ values ensure satisfactory adjustment of the quadratic model to the experimental results. It can be inferred that only 3.23 (COD removal) and 4.57 (TSS removal) of the variability in the responses were not explained for $\mathrm{FeCl}_{3} 6 \mathrm{H}_{2} \mathrm{O}$ coagulant. In addition, only 5.44 (COD removal) and 7.41 (TSS removal) of the variability in the responses were not explained for $\mathrm{Al}_{2}\left(\mathrm{SO}_{4}\right)_{3} 18 \mathrm{H}_{2} \mathrm{O}$ coagulant. The model Fvalues implies that the models are significant for COD and TSS removal efficiencies (Table 5 and Table 6).

Table 3. The experimental design matrix and actual values of responses by $\mathrm{FeCl}_{3} 6 \mathrm{H}_{2} \mathrm{O}$ coagulant

\begin{tabular}{cccccc}
\hline Run & Independent variables & & Responses & \\
\hline & pH & Dosage, $\mathbf{m g} / \mathbf{L}$ & $\begin{array}{c}\text { Reaction } \\
\text { time, } \mathbf{m i n}\end{array}$ & COD (\%) & TSS (\%) \\
\hline 1 & 5 & 500 & 15 & 21.9 & 85.9 \\
2 & 9 & 500 & 15 & 22.9 & 87.2 \\
3 & 5 & 1500 & 15 & 30.9 & 87.5 \\
4 & 9 & 1500 & 15 & 38.6 & 92.8 \\
5 & 5 & 1000 & 5 & 26.4 & 49.7 \\
6 & 9 & 1000 & 5 & 28.2 & 67.7 \\
7 & 5 & 1000 & 25 & 28.2 & 69.5 \\
8 & 9 & 1000 & 25 & 34.8 & 74.7 \\
9 & 7 & 500 & 5 & 28.2 & 70.1 \\
10 & 7 & 1500 & 5 & 37.7 & 82.8 \\
11 & 7 & 500 & 25 & 21.9 & 85.1 \\
12 & 7 & 1500 & 25 & 42.7 & 92.2 \\
13 & 7 & 1000 & 15 & 28.2 & 72.7 \\
14 & 7 & 1000 & 15 & 28.7 & 80.1 \\
15 & 7 & 1000 & 15 & 29.8 & 77.3 \\
\hline
\end{tabular}

Table 4. The experimental design matrix and actual values of responses by $\mathrm{Al}_{2}\left(\mathrm{SO}_{4}\right)_{3} 18 \mathrm{H}_{2} \mathrm{O}$ coagulant.

\begin{tabular}{cccccc}
\hline Run & \multicolumn{3}{c}{ Independent variables } & \multicolumn{2}{c}{ Responses } \\
\hline & pH & Dosage, $\mathbf{m g} / \mathbf{L}$ & $\begin{array}{c}\text { Reaction } \\
\text { time, } \mathbf{\text { min }}\end{array}$ & COD (\%) & TSS (\%) \\
\hline 1 & 5 & 500 & 15 & 19.7 & 77.0 \\
2 & 9 & 500 & 15 & 22.4 & 82.8 \\
3 & 5 & 1500 & 15 & 27.1 & 84.8 \\
4 & 9 & 1500 & 15 & 30.8 & 91.2 \\
5 & 5 & 1000 & 5 & 20.8 & 76.5 \\
6 & 9 & 1000 & 5 & 25.6 & 85.5 \\
7 & 5 & 1000 & 25 & 22.9 & 80.1 \\
8 & 9 & 1000 & 25 & 27.7 & 89.4 \\
9 & 7 & 500 & 5 & 22.9 & 72.8 \\
10 & 7 & 1500 & 5 & 27.7 & 89.7 \\
11 & 7 & 500 & 25 & 22.9 & 87.2 \\
12 & 7 & 1500 & 25 & 28.7 & 95.5 \\
13 & 7 & 1000 & 15 & 25.0 & 80.4 \\
14 & 7 & 1000 & 15 & 24.5 & 81.6 \\
15 & 7 & 1000 & 15 & 26.1 & 83.2 \\
\hline
\end{tabular}


The associated $\mathrm{p}$ value was used to estimate whether statistical significance is large enough [19]. The lower values of Prob $>\mathrm{F}(<0.05)$ imply that the model terms are significant, whereas higher values than 0.1 show that the model terms are insignificant at $95 \%$ probability level [20]. As it can be seen from Table 5, response surface quadratic models for independent variables were significant at $5 \%$ confidence level since $\mathrm{p}$ values were less than 0.05 . F value and $\mathrm{p}$ value were determined to be 16.62 and 0.003226 for COD removal, 11.60 and 0.007403 for TSS removal, showing that the models are significant. It can be seen from Table 5, $\mathrm{pH}$ and dosage of linear coefficients and dosage*time of interactive coefficients has significant effect, whereas all the rest have insignificant effect on COD removal. $\mathrm{pH}$ and reaction time of linear coefficients, dosage*dosage and reaction time*reaction time of quadratic coefficients have significant effect on TSS removal.

As it can be seen from Table $6, \mathrm{~F}$ value and $\mathrm{p}$ value were determined to be 9.61 and 0.011313 for COD removal, 6.94 and 0.022995 for TSS removal, showing that the models are significant. It can be seen from Table $6, \mathrm{pH}$ and dosage of linear coefficients have significant effect, whereas all the rest have insignificant effect on COD removal. $\mathrm{pH}$, dosage and reaction time of linear coefficients, have significant effect on TSS removal.

Table 5. ANOVA results for responses by $\mathrm{FeCl}_{3} 6 \mathrm{H}_{2} \mathrm{O}$ coagulant.

\begin{tabular}{|c|c|c|c|c|c|}
\hline COD removal & Sum of Squares & Df & Mean Square & f & $\mathbf{p}$ \\
\hline Model & 511.7746 & 9 & 56.86384 & 16.62 & 0.003226 \\
\hline $\mathrm{X}_{1}$ & 36.5513 & 1 & 36.5513 & 10.73 & 0.0221 \\
\hline $\mathrm{X}_{2}$ & 378.125 & 1 & 378.125 & 111.00 & 0.0001 \\
\hline $\mathrm{X}_{3}$ & 6.30125 & 1 & 6.30125 & 1.85 & 0.2319 \\
\hline $\mathrm{X}_{1} \mathrm{X}_{1}$ & 11.6331 & 1 & 11.6331 & 3.41 & 0.1239 \\
\hline $\mathrm{X}_{1} \mathrm{X}_{2}$ & 11.2225 & 1 & 11.2225 & 3.29 & 0.1292 \\
\hline $\mathrm{X}_{1} \mathrm{X}_{3}$ & 5.76 & 1 & 5.76 & 1.69 & 0.2502 \\
\hline $\mathrm{X}_{2} \mathrm{X}_{2}$ & 7.76308 & 1 & 7.76308 & 2.28 & 0.1915 \\
\hline $\mathrm{X}_{2} \mathrm{X}_{3}$ & 31.9225 & 1 & 31.9225 & 9.37 & 0.0281 \\
\hline $\mathrm{X}_{3} \mathrm{X}_{3}$ & 19.11 & 1 & 19.11 & 5.61 & 0.0641 \\
\hline Total error & 17.0325 & 5 & 3.4065 & & \\
\hline Total (corr.) & 527.616 & 14 & & & \\
\hline \multicolumn{6}{|l|}{$\mathrm{R}^{2}=96.77 \%$} \\
\hline TSS removal & Sum of Squares & Df & Mean Square & $\mathbf{f}$ & $\mathbf{p}$ \\
\hline Model & 1732.147 & 9 & 192.4608 & 11.60 & 0.007403 \\
\hline $\mathrm{X}_{1}$ & 111.005 & 1 & 111.005 & 6.69 & 0.0490 \\
\hline $\mathrm{X}_{2}$ & 91.125 & 1 & 91.125 & 5.49 & 0.0661 \\
\hline $\mathrm{X}_{3}$ & 327.68 & 1 & 327.68 & 19.76 & 0.0067 \\
\hline $\mathrm{X}_{1} \mathrm{X}_{1}$ & 27.9231 & 1 & 27.9231 & 1.68 & 0.2511 \\
\hline $\mathrm{X}_{1} \mathrm{X}_{2}$ & 4.0 & 1 & 4.0 & 0.24 & 0.6442 \\
\hline $\mathrm{X}_{1} \mathrm{X}_{3}$ & 40.96 & 1 & 40.96 & 2.47 & 0.1769 \\
\hline $\mathrm{X}_{2} \mathrm{X}_{2}$ & 765.637 & 1 & 765.637 & 46.16 & 0.0011 \\
\hline $\mathrm{X}_{2} \mathrm{X}_{3}$ & 7.84 & 1 & 7.84 & 0.47 & 0.5223 \\
\hline $\mathrm{X}_{3} \mathrm{X}_{3}$ & 269.917 & 1 & 269.917 & 16.27 & 0.0100 \\
\hline Total error & 82.93 & 5 & 16.586 & & \\
\hline Total (corr.) & 1815.08 & 14 & & & \\
\hline $\mathrm{R}^{2}=95.43 \%$ & & & & & \\
\hline
\end{tabular}


Table 6. ANOVA results for responses by $\mathrm{Al}_{2}\left(\mathrm{SO}_{4}\right)_{3} 18 \mathrm{H}_{2} \mathrm{O}$ coagulant.

\begin{tabular}{|c|c|c|c|c|c|}
\hline COD removal & Sum of Squares & Df & Mean Square & $\mathbf{f}$ & $\mathbf{p}$ \\
\hline Model & 126.2241 & 9 & 14.0249 & 9.61 & 0.011313 \\
\hline $\mathrm{X}_{1}$ & 32.0 & 1 & 32.0 & 21.98 & 0.0054 \\
\hline $\mathrm{X}_{2}$ & 87.12 & 1 & 87.12 & 59.84 & 0.0006 \\
\hline $\mathrm{X}_{3}$ & 3.38 & 1 & 3.38 & 2.32 & 0.1881 \\
\hline $\mathrm{X}_{1} \mathrm{X}_{1}$ & 2.07692 & 1 & 2.07692 & 1.43 & 0.2859 \\
\hline $\mathrm{X}_{1} \mathrm{X}_{2}$ & 0.25 & 1 & 0.25 & 0.17 & 0.6958 \\
\hline $\mathrm{X}_{1} \mathrm{X}_{3}$ & 0.0 & 1 & 0.0 & 0.00 & 1.0000 \\
\hline $\mathrm{X}_{2} \mathrm{X}_{2}$ & 1.11692 & 1 & 1.11692 & 0.77 & 0.4212 \\
\hline $\mathrm{X}_{2} \mathrm{X}_{3}$ & 0.25 & 1 & 0.25 & 0.17 & 0.6958 \\
\hline$X_{3} X_{3}$ & 0.147692 & 1 & 0.147692 & 0.10 & 0.7630 \\
\hline Total error & 7.28 & 5 & 1.456 & & \\
\hline Total (corr.) & 133.857 & 14 & & & \\
\hline \multicolumn{6}{|l|}{$\mathrm{R}^{2}=94.56 \%$} \\
\hline TSS removal & Sum of Squares & Df & Mean Square & $\mathbf{f}$ & $\mathbf{p}$ \\
\hline Model & 486.3332 & 9 & 54.03702 & 6.94 & 0.022995 \\
\hline $\mathrm{X}_{1}$ & 116.281 & 1 & 116.281 & 14.95 & 0.0118 \\
\hline $\mathrm{X}_{2}$ & 214.245 & 1 & 214.245 & 27.55 & 0.0033 \\
\hline $\mathrm{X}_{3}$ & 95.9113 & 1 & 95.9113 & 12.33 & 0.0171 \\
\hline $\mathrm{X}_{1} \mathrm{X}_{1}$ & 1.34776 & 1 & 1.34776 & 0.17 & 0.6945 \\
\hline $\mathrm{X}_{1} \mathrm{X}_{2}$ & 0.09 & 1 & 0.09 & 0.01 & 0.9185 \\
\hline $\mathrm{X}_{1} \mathrm{X}_{3}$ & 0.0225 & 1 & 0.0225 & 0.00 & 0.9592 \\
\hline $\mathrm{X}_{2} \mathrm{X}_{2}$ & 29.3801 & 1 & 29.3801 & 3.78 & 0.1096 \\
\hline $\mathrm{X}_{2} \mathrm{X}_{3}$ & 18.49 & 1 & 18.49 & 2.38 & 0.1837 \\
\hline $\mathrm{X}_{3} \mathrm{X}_{3}$ & 11.2539 & 1 & 11.2539 & 1.45 & 0.2828 \\
\hline Total error & 38.8842 & 5 & 7.77683 & & \\
\hline Total (corr.) & 525.217 & 14 & & & \\
\hline $\mathrm{R}^{2}=92.59 \%$ & & & & & \\
\hline
\end{tabular}

The three-dimensional plots of the regression models are given in Figures 1 and 2 for the graphical explanation of the interactions. The software-based response surface plots provide a three-dimensional interpretation of COD and TSS removal efficiencies surface with varying combinations of independent variables. All response surface plots have clear peaks, meaning that the optimum conditions for maximum values of the responses are attributed to all variables in the design space. 3D surface plots indicate that at optimum operating conditions COD and TSS removal efficiencies were found to be maximum but moving away from these points indicates reduction in removal efficiencies, which means an increase or decrease in any of the tested variables is desired. As can be seen in Figure 1 and 2, COD and TSS removal efficiencies were determined to be much higher by process using $\mathrm{FeCl}_{3} 6 \mathrm{H}_{2} \mathrm{O}$ than $\mathrm{Al}_{2}\left(\mathrm{SO}_{4}\right)_{3} 18 \mathrm{H}_{2} \mathrm{O}$ coagulant.

Table 7 shows the experimental results and the optimum conditions for both processes. Based on response surface models, optimum conditions for maximum COD and TSS removal from food industry wastewater were determined. Optimized conditions for COD removal were obtained at $\mathrm{pH} 9$, dosage $1500 \mathrm{mg} / \mathrm{L}$ and reaction time $25 \mathrm{~min}$ and $\mathrm{pH}$ 9, dosage $1493 \mathrm{mg} / \mathrm{L}$ and reaction time $25 \mathrm{~min}$ for process using $\mathrm{FeCl}_{3} 6 \mathrm{H}_{2} \mathrm{O}$ and $\mathrm{Al}_{2}\left(\mathrm{SO}_{4}\right)_{3} 18 \mathrm{H}_{2} \mathrm{O}$ coagulants, respectively. Under these 

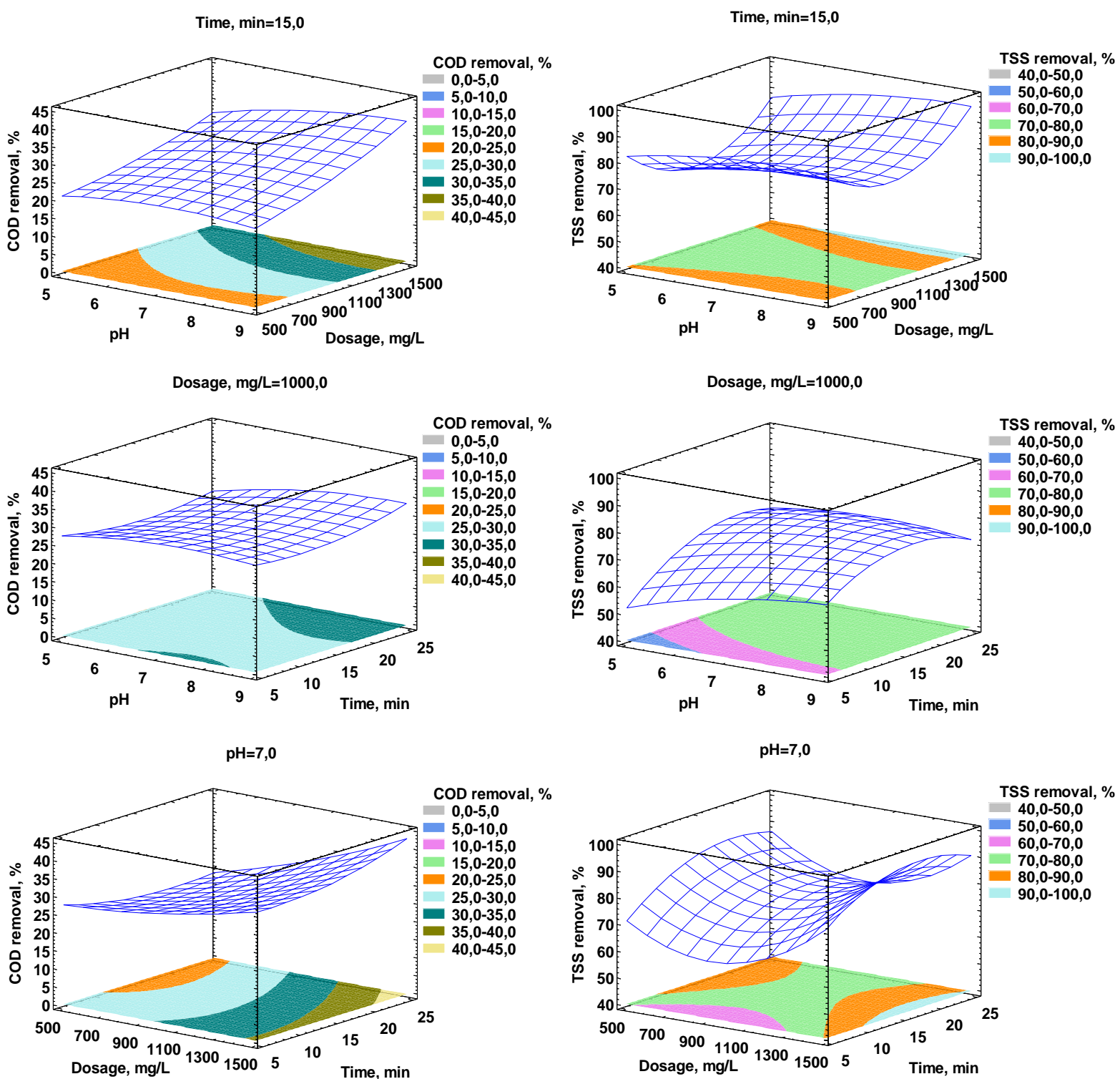

Figure 1. Response surface graphs for the process using $\mathrm{FeCl}_{3} 6 \mathrm{H}_{2} \mathrm{O}$ coagulant .

conditions, $46.4 \%$ and $31.2 \%$ of $\mathrm{COD}$ removals for $\mathrm{FeCl}_{3} 6 \mathrm{H}_{2} \mathrm{O}$ and $\mathrm{Al}_{2}\left(\mathrm{SO}_{4}\right)_{3} 18 \mathrm{H}_{2} \mathrm{O}$ coagulants were obtained, respectively. The COD removal efficiencies for both coagulants in this study are comparatively higher than that of Ozbey-Unal et al. [12] who achieved to remove $13.6 \%$ and $10.5 \%$ of $\mathrm{COD}$ with $\mathrm{FeCl}_{3}$ and $\mathrm{Al}_{2}\left(\mathrm{SO}_{4}\right)_{3}$ coagulants, respectively. Also COD removal with $\mathrm{FeCl}_{3} 6 \mathrm{H}_{2} \mathrm{O}$ in this study is higher than Weng et al. [13] who provided $14 \%$ removal. On the other hand, Can et al. [11] managed to remove $51 \%$ of COD by using $\mathrm{Al}_{2}\left(\mathrm{SO}_{4}\right)_{3}$ in coffee and coffee products wastewater.

Optimized conditions for TSS removal were obtained at $\mathrm{pH} 8.5$, dosage $1500 \mathrm{mg} / \mathrm{L}$ and reaction time $16.5 \mathrm{~min}$ and $\mathrm{pH} 9$, dosage $1498 \mathrm{mg} / \mathrm{L}$ and reaction time $25 \mathrm{~min}$ for process using $\mathrm{FeCl}_{3} 6 \mathrm{H}_{2} \mathrm{O}$ and $\mathrm{Al}_{2}\left(\mathrm{SO}_{4}\right)_{3} 18 \mathrm{H}_{2} \mathrm{O}$ coagulants, respectively. Under these conditions, $96.7 \%$ and $96.2 \%$ of TSS removals for $\mathrm{FeCl}_{3} 6 \mathrm{H}_{2} \mathrm{O}$ and
$\mathrm{Al}_{2}\left(\mathrm{SO}_{4}\right)_{3} 18 \mathrm{H}_{2} \mathrm{O}$ coagulants were obtained, respectively. For both coagulants TSS removal is considerable higher than Ozbey-Unal et al. [12] who removed $6 \%$ and $3.2 \%$ of TSS by $\mathrm{FeCl}_{3}$ and $\mathrm{Al}_{2}\left(\mathrm{SO}_{4}\right)_{3}$ coagulants, respectively. In order to confirm the accuracy of the predicted model and the reliability of the optimum conditions, additional verification experiments were performed under optimum conditions. It was found that the experimental values were complied well with the predicted values. The verification experiment results were 43 and $30.3 \%$ for COD removal and 87.8 and $86.2 \%$ for TSS removal with $\mathrm{FeCl}_{3} 6 \mathrm{H}_{2} \mathrm{O}$ and $\mathrm{Al}_{2}\left(\mathrm{SO}_{4}\right)_{3} 18 \mathrm{H}_{2} \mathrm{O}$ coagulants, respectively.

Predicted and actual responses are presented in Figure 3. For a specific run, actual values are experimentally measured reaction information and the expected values are assessed from the model and produced using the equation of classification. 

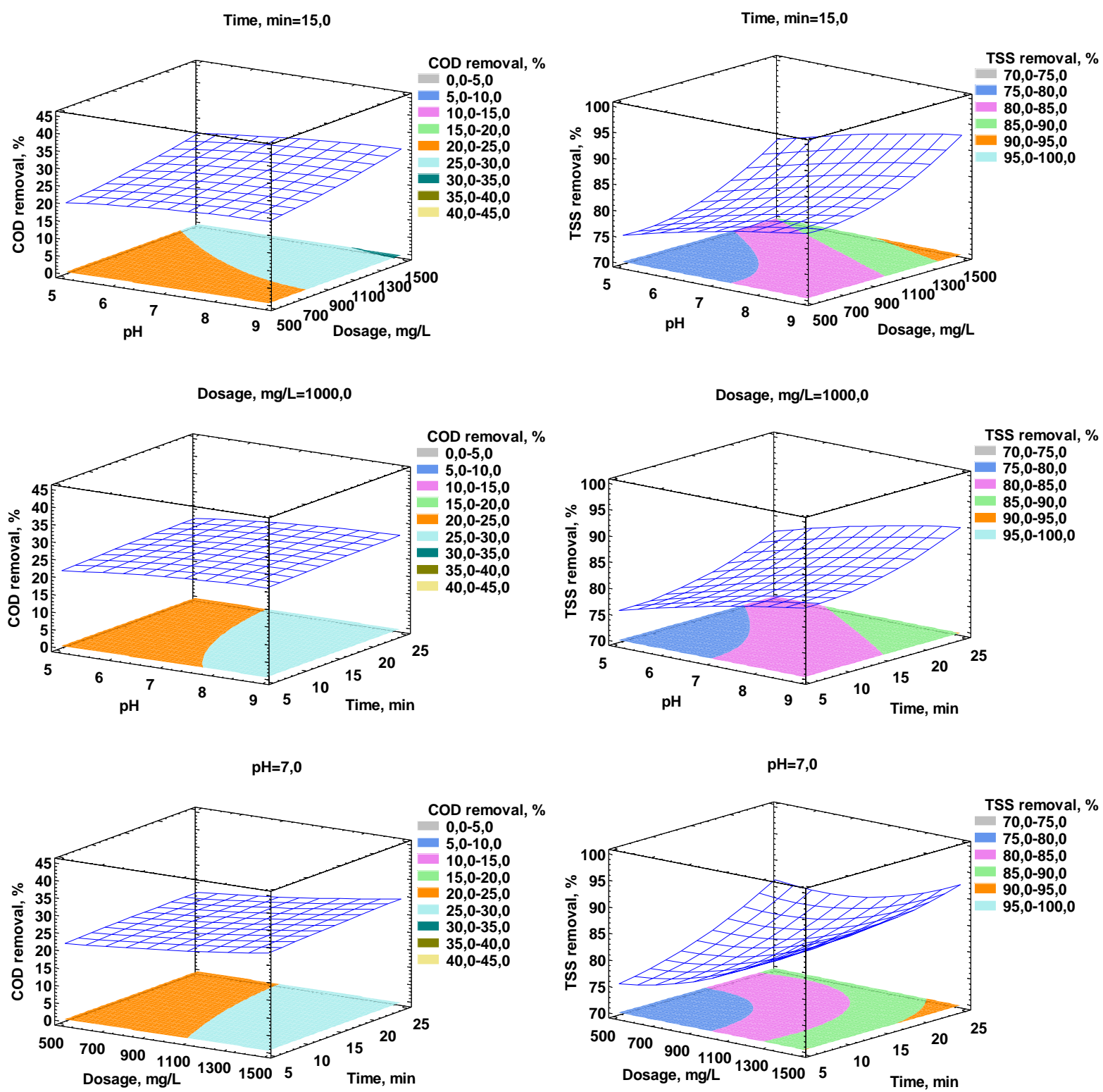

Figure 2. Response surface graphs for the process using $\mathrm{Al}_{2}\left(\mathrm{SO}_{4}\right)_{3} 18 \mathrm{H}_{2} \mathrm{O}$ coagulant.

Table 7. Optimum operating conditions of maximum removal of responses.

\begin{tabular}{ccccc}
\hline \multirow{3}{*}{ Independent variables } & \multicolumn{4}{c}{ Coagulant type } \\
\cline { 2 - 5 } & \multicolumn{2}{c}{$\mathbf{F e C l}_{\mathbf{3}} \mathbf{6} \mathbf{H}_{\mathbf{2}} \mathbf{O}$} & $\mathbf{A l}\left(\mathbf{S O}_{\mathbf{4}}\right)_{\mathbf{3}} \mathbf{1 8} \mathbf{H}_{\mathbf{2}} \mathbf{O}$ \\
\cline { 2 - 5 } & $\mathbf{C O D}$ & $\mathbf{T S S}$ & $\mathbf{C O D}$ & $\mathbf{T S S}$ \\
\hline $\mathrm{pH}$ & 9 & 8.5 & 9 & 9 \\
Dosage, $\mathrm{mg} / \mathrm{L}$ & 1500 & 1500 & 1493 & 1498 \\
Time, $\mathrm{min}$ & 25 & 16.5 & 25 & 25 \\
Removal $(\%)$ & 46.4 & 96.7 & 31.2 & 96.2 \\
\hline
\end{tabular}



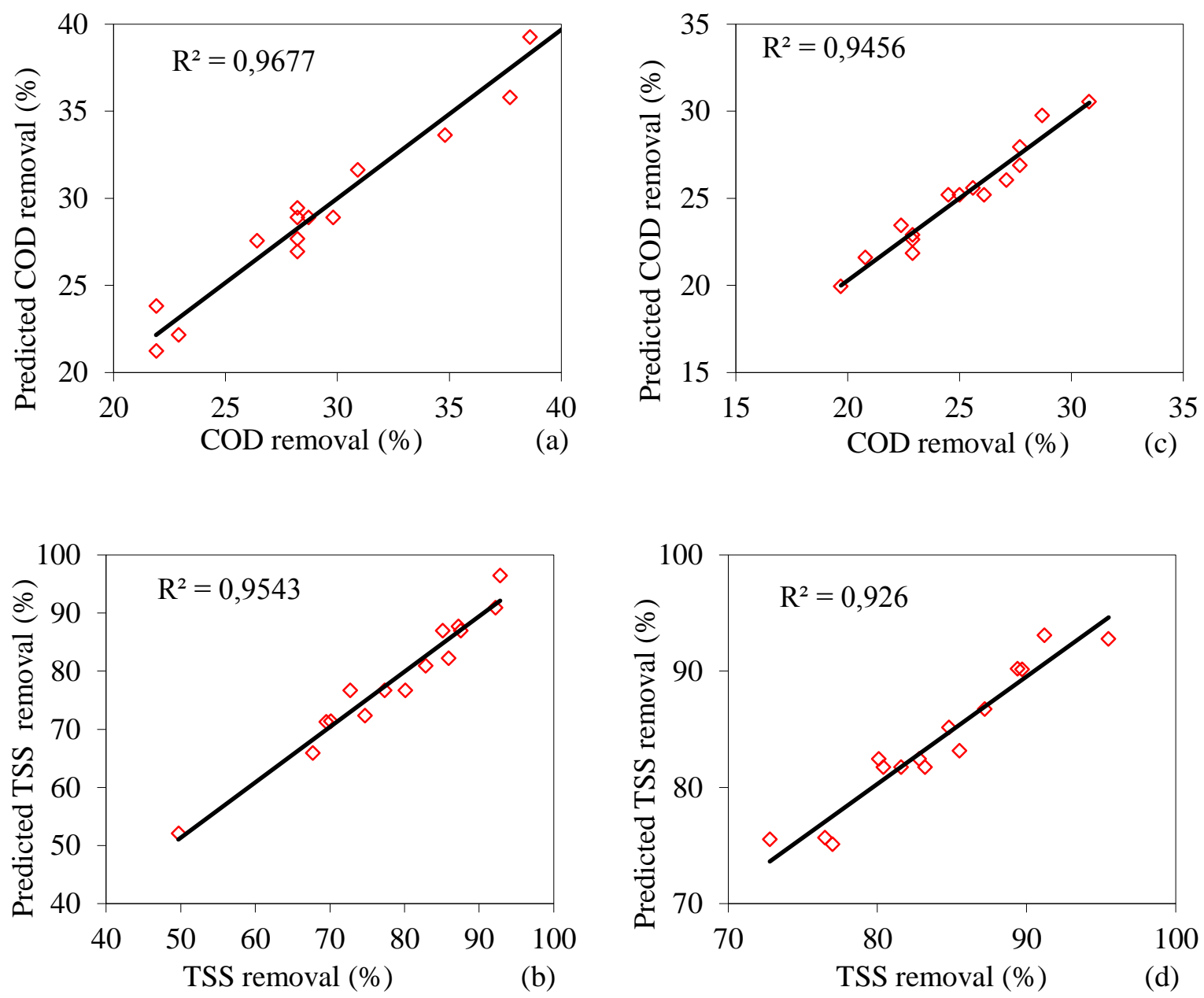

Figure 3. Comparison of predicted and experimental values for the processes using $\mathrm{FeCl}_{3} 6 \mathrm{H}_{2} \mathrm{O}$ (a-b) and $\mathrm{Al}_{2}\left(\mathrm{SO}_{4}\right)_{3} 18 \mathrm{H}_{2} \mathrm{O}$ (c-d) coagulants.

\section{Conclusions}

$>$ RSM and CCD were applied to model and optimize the performance of coagulation processes using $\mathrm{FeCl}_{3} 6 \mathrm{H}_{2} \mathrm{O}$ and $\mathrm{Al}_{2}\left(\mathrm{SO}_{4}\right)_{3} 18 \mathrm{H}_{2} \mathrm{O}$ and to determine the optimal experimental conditions for COD and TSS removal from food industry wastewater.

$>$ Coagulation processes using $\mathrm{FeCl}_{3} 6 \mathrm{H}_{2} \mathrm{O}$ and $\mathrm{Al}_{2}\left(\mathrm{SO}_{4}\right)_{3} 18 \mathrm{H}_{2} \mathrm{O}$ were conducted for the treatment of food industry wastewater to achieve maximum COD and TSS removal. $\mathrm{pH}$ of wastewater, coagulant dosage and reaction time were investigated and found to be important parameters for effective treatment of food industry wastewater.

> The results of the quadratic model and analysis of variance developed in this study showed a good agreement between experimental and predicted values and high corelaiton coefficient values. $\mathrm{R}^{2}$ coefficients of the quadratic model were found to be $96.77 \%$ (COD removal) and $95.43 \%$ (TSS removal) for $\mathrm{FeCl}_{3} 6 \mathrm{H}_{2} \mathrm{O}$ coagulant and $94.56 \%$ (COD removal) and $92.59 \%$ (TSS removal) for $\mathrm{Al}_{2}\left(\mathrm{SO}_{4}\right)_{3} 18 \mathrm{H}_{2} \mathrm{O}$ coagulant.

At optimum conditions $46.4 \%$ of COD and $96.7 \%$ of TSS removal were achieved by $\mathrm{FeCl}_{3} 6 \mathrm{H}_{2} \mathrm{O}$ coagulant whereas $31.2 \%$ of $\mathrm{COD}$ and $96.2 \%$ of TSS removals were achieved by $\mathrm{Al}_{2}\left(\mathrm{SO}_{4}\right)_{3} 18 \mathrm{H}_{2} \mathrm{O}$ coagulant. The coagulation process using $\mathrm{FeCl}_{3} 6 \mathrm{H}_{2} \mathrm{O}$ coagulant offered higher removal efficiency for COD but no significant difference for TSS removal efficiency among processes. Hence, coagulation process using $\mathrm{FeCl}_{3} 6 \mathrm{H}_{2} \mathrm{O}$ coagulant can be recommended as a powerful pre-treatment technique for food industry wastewater.

\section{Author's Contributions}

Senem Yazici Guvenc: Performed the model, design of the experiments, statistical analyses, and the experiments, wrote the manuscript.

Emine Can Guven: Performed the experiments, wrote the manuscript. 


\section{Ethics}

There are no ethical issues after the publication of this manuscript.

\section{References}

1. Amuda, OS, Amoo, IA, Ajayi, OO. 2006. Performance optimization of coagulant/flocculant in the treatment of wastewater from a beverage industry. Journal of Hazardous Materials; 129(1-3): 69-72.

2. Amokrane, A, Comel, C, Veron, J. 1997. Landfill leachates pretreatment by coagulation-flocculation. Water Research 31(11): 2775-2782.

3. Amuda, OS, Amoo, IA. 2007. Coagulation/flocculation process and sludge conditioning in beverage industrial wastewater treatment. Journal of Hazardous Materials; 141(3): 778-83.

4. Gao, B, Yue, Q. 2005. Effect of $\mathrm{SO}_{4}{ }^{2-} / \mathrm{Al}^{3+}$ ratio and $\mathrm{OH}-/ \mathrm{Al}^{3+}$ value on the characterization of coagulant poly-aluminumchloride-sulfate (PACS) and its coagulation performance in water treatment. Chemosphere; 61(4): 579-584.

5. Song, Z, Williams, CJ, Edyvean, R. 2004. Treatment of tannery wastewater by chemical coagulation. Desalination; 164249-259.

6. Randtke, SJ. 1988. Organic contaminant removal by coagulation and related process combinations. Journal-American Water Works Association; 80(5): 40-56.

7. Pavón-Silva, T, Pacheco-Salazar, V, Carlos Sánchez-Meza, J, Roa-Morales, G, Colín-Cruz, A. 2009. Physicochemical and biological combined treatment applied to a food industry wastewater for reuse. Journal of Environmental Science and Health - Part A Toxic/Hazardous Substances and Environmental Engineering; 44(1): 108-115.

8. Varank, G, Yazici Guvenc, S, Demir, A. 2018. A comparative study of electrocoagulation and electro-Fenton for food industry wastewater treatment: Multiple response optimization and cos analysis. Separation Science and Technology (Philadelphia) 53(17): 2727-2740

9. Beltran de Heredia, J, Dominguez, JR, Lopez, R. 2004. Treatment of cork process wastewater by a successive chemical- physical method. Journal of Agricultural and Food Chemistry; 52(14) 4501-4507.

10. Minhalma, M, De Pinho, MN. 2001 Flocculation/flotation/ultrafiltration integrated process for the treatment of cork processing wastewaters. Environmental Science \& Technology; 35(24): 4916-4921.

11. Can, OT, Gengec, E, Kobya, M. 2019. TOC and COD removal from instant coffee and coffee products production wastewater by chemical coagulation assisted electrooxidation. Journal of Water Process Engineering; 28: 28-35.

12. Ozbey-Unal, B, Balcik-Canbolat, C, Dizge, N, Keskinler, B 2018. Treatability studies on optimizing coagulant type and dosage in combined coagulation/membrane processes for table olive processing wastewater. Journal of Water Process Engineering; 26: 301-307.

13. Weng, SC, Jacangelo, JG, Schwab, KJ. 2019. Sustainable practice for the food industry: assessment of selected treatment options for reclamation of washwater from vegetable processing. International Journal of Environmental Science and Technology; 16(3): 1369-1378.

14. Li, H, Zhou, S, Sun, Y, Lv, J. 2010. Application of response surface methodology to the advanced treatment of biologically stabilized landfill leachate using Fenton's reagent. Waste
Management; 30(11): 2122-2129.

15. Herney-Ramirez, J, Lampinen, M, Vicente, MA, Costa, CA, Madeira, LM. 2008. Experimental design to optimize the oxidation of Orange II dye solution using a clay-based Fentonlike catalyst. Industrial \& Engineering Chemistry Research; 47(2): 284-294.

16. Mohajeri, L, Aziz, HA, Isa, MH, Zahed, MA. 2010. A statistical experiment design approach for optimizing biodegradation of weathered crude oil in coastal sediments. Bioresource Technology; 101(3): 893-900.

17. APHA. 2005. Standard Methods for Examination of Water and Wastewater. 21th ed. American Public Health Association.

18. Dutta, S, Bhattacharyya, A, Ganguly, A, Gupta, S, Basu, S. 2011. Application of response surface methodology for preparation of low-cost adsorbent from citrus fruit peel and for removal of methylene blue. Desalination; 275(1-3): 26-36.

19. Sridhar, R, Sivakumar, V, Thirugnanasambandham, K. 2016. Response surface modeling and optimization of upflow anaerobic sludge blanket reactor process parameters for the treatment of bagasse based pulp and paper industry wastewater. Desalination and Water Treatment; 57(10): 4345-4356

20. Kim, S-C. 2016. Application of response surface method as an experimental design to optimize coagulation-flocculation process for pre-treating paper wastewater. Journal of Industrial and Engineering Chemistry; 3893-102. 